\title{
Author Correction: The value of US coral reefs for flood risk reduction
}

Borja G. Reguero (1), Curt D. Storlazzi (D), Ann E. Gibbs (1D, James B. Shope, Aaron D. Cole, Kristen A. Cumming and Michael W. Beck (1D)

Correction to: Nature Sustainability https://doi.org/10.1038/s41893-021-00706-6, published online 15 April 2021.

In the version of this Article originally published, the second sentence of the Acknowledgements erroneously included the text 'in part' with regards to the financial support. The sentence 'This research was financially supported in part by the US Department of Interior, USGS through the Coastal and Marine Hazards and Resources Program's Coral Reef Project and the US Department of Interior, Office of Insular Affairs.' should have been 'This research was financially supported by the US Department of Interior, USGS through the Coastal and Marine Hazards and Resources Program's Coral Reef Project and the US Department of Interior, Office of Insular Affairs.' This has now been corrected.

Published online: 30 April 2021

https://doi.org/10.1038/s41893-021-00724-4

This is a U.S. government work and not under copyright protection in the U.S.; foreign copyright protection may apply 2021 